\title{
The Long-Run Relationship between Economic Growth and Tourism Revenue: The Case of Turkey and TRNC
}

\section{Ekonomik Büyüme ile Turizm Geliri Arasındaki Uzun Dönemli İlişki: Türkiye ve KKTC Örneği}

\author{
Mehmet ÇINAR* \\ Barıș ÜLKER**
}

\begin{abstract}
Tourism-led growth hypothesis has been researched by several domestic and international studies. However, there is no consensus on the results of these studies since different countries with different data and different approaches are used for each of them. In this study, the long-run relationship between tourism and economic growth for Turkey and Turkish Republic of Northern Cyprus have been researched by using annual data for tourism income and GDP between 1977 and 2013, and the role and strength of tourism sector in economic growth for both countries are investigated. ARDL bounds test are used for this study. According to the results, for Turkey, both short and long term relationships between tourism revenues and GDP are found, and there is also a unidirectional causality relationship from tourism revenues to GDP. The results also indicate that tourism-led growth hypothesis is valid, and the policies targeting development of tourism sector are efficient in both short and long term for Turkey. However, when the relationship between tourism revenues and GDP for TRNC is tested, co-integration relationship cannot be found between these two variables so, we can conclude that tourism-led growth hypothesis is not valid for TRNC.
\end{abstract}

Keywords: Economic Growth, Tourism Revenue, ARDL Bounds Test, Turkey, TRNC.

Öz

Turizm temelli büyüme hipotezi, birçok ulusal ve uluslararası araştırmada araştırılmıştır. Buna rağmen her çalışmada farklı yöntem, farklı veri yapısı ve farklı ülkeler kullanılsa da, bu çalışma sonuçlarında bir görüş birliğine varılmamaktadır. Bu çalışmada, 1977 ve 2013 yılları arasında GDP ve turizm gelirleri yıllık verileri kullanılarak Türkiye ve Kuzey Kıbrıs Türk Cumhuriyeti için ekonomik büyüme ve turizm arasındaki uzun dönem ilişkisi araştırılmaktadır. Çalışmada ARDL sınır testi kullanılmıştır. Çalışma sonuçlarına göre, Türkiye için turizm gelirleri ve GDP arasında hem kısa hem de uzun dönemde ilişki olduğu ve turizm gelirlerinden GDP'ye doğru tek yönlü bir dolaylı nedensellik sonucuna ulaşılmıştır. Sonuçlar turizm temelli büyüme hipotezini desteklemekte ve hem kısa hem de uzun dönemde turizm sektörünün gelişimini hedefleyen politikalar etkindir. Fakat KKTC için turizm geliri ve GDP arasındaki ilişki için uygulanan test, KKTC için bu iki değişken arasında uzun dönemli bir ilişki olmadığını göstermektedir. Dolayısıyla KKTC için turizm temelli büyüme hipotezinin geçerli olmadığı bulunmuştur.

Anahtar Kelimeler: Ekonomik Büyüme, Turizm Gelirleri, ARDL Sınır Testi, Türkiye, KKTC.

\section{Introduction}

The tourism sector becomes more essential for the developed and developing countries as it is a sector that grows day by day. When tourism is analyzed from its conceptual aspect, the definition could be stated as it is an activity which people travel different places other than their natural environment for entertainment, business or other purposes and accommodate in those places. When it is analyzed from the economic aspect, the revenues obtained from tourism have effects on the factors that support economic growth such as balance of international payments, tax revenues, foreign currency inflow, employment and level of income. Beside these, it works as a bridge among the countries for the interaction among the different cultures is very common in tourism. Most of the countries implement different strategies to support development of tourism by considering its economic and social advantages.

It starts from 1980s for Turkey as tourism has become a significant sector that develops fast and plays important role on the economy. Since the beginning of 1980s, beside the promotions towards tourism sector, the international expansions followed by Turkey helped

\footnotetext{
* Doç. Dr. Uludağ Üniversitesi, Iktisadi ve Idari Bilimler Fakültesi Ekonometri Bölümü, mcinar@uludag.edu.tr.

** Arş. Gör., Dicle Üniversitesi, İktisadi ve İdari Bilimler Fakültesi İktisat Bölümü, ulker.baris@ gmail.com.
} 
rapid development of this sector and made the country a popular destination chosen by international visitors.

Turkish Republic of Northern Cyprus, which was found in 1974, is also very keen on tourism sector. According to the data of $2013,9 \%$ of the GDP of TRNC is created by the tourism sector whereas $6 \%$ of total employment is provided by the tourism sector. The government of TRNC also strongly promotes the tourism sector as the island is very suitable for touristic activities. In the second section of the study contains concept of tourism and economic growth, and in section three, there is literature review. Section four is methodology section and in this section take places the data set and method used in the analysis. In the final section conclusion is conducted.

\section{Tourism and Economic Growth}

The main macroeconomic effect of the tourism sector is on economic growth. The relationship between tourism revenues and economic growth has been widely researched by many countries for the recent years.. The causality relationship between tourism revenues and economic growth is an important factor for policy implementers and implementation of tourism policies correctly, that will help tourism sector to develop, has become an important issue to be emphasized (Chou, 2013, p. 226).

Tourism has an important role for diversification of economic activities, especially in developing countries. It has become a sector to be supported as many low-income countries have suitable natural sources for tourism and ready population to be employed in tourism sector (Lejarraga and Walkenhorst, 2013, p. 2). In many developing countries, tourism works as a sector that provides highest employment and foreign currency inflow (Narayan, 2007, p. 651). For example, according to the reports of World Travel and Tourism Council, the direct and indirect revenues obtained by tourism creates 33,1\% of total GDP in Fiji (WTTC, 2006, p. 13). This data reveals the positive effect of the sector for the developing countries which has a wide potential for the growth of tourism.

The effect of the tourism sector on economy is researched by tourism led growth (TLG) hypothesis. TLG is derived from export-led growth hypothesis. ELG is a hypothesis claims that increase of export will increase economic growth. According to this, the rate of economic growth can be increased not only by increasing the amount of employment and capital within the country, but also increasing the capacity of export (Smith, 2001, p. 1). Export does not only help for the transfer of technologic information and skills (Kruger, 1980, p. 6), at the same time, it decreases pressure of the foreign exchange and decrease of this pressure leads increase of import of capital and intermediate goods (McKinnon, 1964, p. 404). International tourism can be considered as either a non-traditional export, which implies a source of receipts, or as a potential strategic factor to development and economic growth (Chang, Khamkaew and McAleer, 2010, p. 4).

The liberalization process had started in Turkey in 1980s, the country encountered a rapid economic growth that includes a blasting expansion of the tourism sector. The statistical numbers also prove that the growth of the tourism sector have e significant share in GDP. The share of tourism in GDP was only $0,6 \%$ in 1980 . However, it increased to $2,8 \%$ by 1985 . As TLG hypothesis is derived from ELG hypothesis, the share of tourism income in total export income also plays a crucial role to take a stop for proving the validity of the hypothesis. The share of tourism income in total export income was $11,2 \%$ in 1980 and it increased to $18,6 \%$ by 1985 . However, the situation is different for TRNC. The share of tourism income decreased from $24,7 \%$ in 1980 to $19,7 \%$ by 2015 . 
TLG hypothesis researches whether tourism and economic growth have long term or short term relationship. The aim of this hypothesis is to determine whether there is a unilateral or bilateral relationship between these two factors (Brida and Pulina, 2010, p. 2). The researches made under the scope of TLG hypothesis have revealed that the tourism sector is effective of economic growth not only in touristic small island countries (Brau and Piglauru, 2007, p. 3), but also in developed countries (Paci and Marrocu, 2013, p. 25).

\section{Literature Review}

The relationship between tourism and economic development has been researched by the usage different of different time periods and different methods. In some of the researches made for the same countries, different results have been found since different methods are used. The methods used in studies are various such as Johansen vector error correction model, Granger causality test (VAR or Toda Yamamoto Model), Structural brake models (Zivot Andrews), Bounds Test with ARDL Model, panel data approach (Brida and Pulina, 2010, p. 8).

Even there are different factors used for the research of economic growth and tourism such as number of incoming visitors or tourism spending, in this work, the relationship between tourism revenues and GDP are used to examine the results. There are also various works has been made to research the relationship between tourism revenues and GDP.

There is no agreement for the validity of TLG Hypothesis for all countries and all time periods. The results of studies have clearly shown that, TLG Hypothesis might me valid of invalid depending on countries, the studied time periods or the methods used by the researches.

Table1: Literature Review of the Studies Related to the Relationship between the Tourism Sector and Economic Growth

\begin{tabular}{|c|c|c|c|c|c|}
\hline $\begin{array}{c}\text { Author and } \\
\text { Year } \\
\end{array}$ & $\begin{array}{l}\text { Study } \\
\text { Period } \\
\end{array}$ & Countries & Variables & Methodology & Result \\
\hline Aslan, 2008 & $\begin{array}{c}1992- \\
2007\end{array}$ & Turkey & $\begin{array}{c}\text { GDP and } \\
\text { International } \\
\text { Tourism Income }\end{array}$ & $\begin{array}{c}\text { Johansen } \\
\text { Cointegration and } \\
\text { Granger Causality } \\
\end{array}$ & $\mathrm{TUR} \rightarrow \mathrm{Y}$ \\
\hline $\begin{array}{l}\text { Dritsakis, } \\
2004\end{array}$ & $\begin{array}{c}1960- \\
2000\end{array}$ & Greece & $\begin{array}{c}\text { GDP and } \\
\text { International } \\
\text { Tourism Income }\end{array}$ & $\begin{array}{c}\text { Johansen and } \\
\text { Juselious } \\
\text { Cointegration and } \\
\text { Granger Causality }\end{array}$ & TUR $\leftrightarrow \mathrm{Y}$ \\
\hline $\begin{array}{l}\text { Kaplan and } \\
\text { Çelik, } 2008\end{array}$ & $\begin{array}{c}1963- \\
2006\end{array}$ & Turkey & $\begin{array}{c}\text { GDP and } \\
\text { International } \\
\text { Tourism Income }\end{array}$ & $\begin{array}{l}\text { Johansen-Juselius } \\
\text { Cointegration and } \\
\text { Granger Causality }\end{array}$ & $\mathrm{TUR} \rightarrow \mathrm{Y}$ \\
\hline $\begin{array}{c}\text { Khalil, Kakar } \\
\text { and } \\
\text { Waliullah, } \\
2007 \\
\end{array}$ & $\begin{array}{l}1960- \\
2005\end{array}$ & Pakistan & $\begin{array}{c}\text { GDP and } \\
\text { International } \\
\text { Tourism Income }\end{array}$ & $\begin{array}{l}\text { Engle - Granger } \\
\text { Cointegration and } \\
\text { Granger Causality }\end{array}$ & TUR $\leftrightarrow \mathrm{Y}$ \\
\hline $\begin{array}{c}\text { K1zilgöl and } \\
\text { Erbaykal, } \\
2008 \\
\end{array}$ & $\begin{array}{c}1992- \\
2006\end{array}$ & Turkey & $\begin{array}{l}\text { GDP and Tourism } \\
\text { Income }\end{array}$ & Granger Causality & TUR $\leftarrow Y$ \\
\hline $\begin{array}{c}\text { Kumar and } \\
\text { Stauvermann, } \\
2016 \\
\end{array}$ & $\begin{array}{l}1978- \\
2014\end{array}$ & Sri Lanka & $\begin{array}{l}\text { GDP and Tourism } \\
\text { Income }\end{array}$ & $\begin{array}{l}\text { ARDL and Toda - } \\
\text { Yamamoto Causality }\end{array}$ & $\mathrm{TUR} \rightarrow \mathrm{Y}$ \\
\hline $\begin{array}{c}\text { Lee and } \\
\text { Chang, } 2008\end{array}$ & $\begin{array}{c}1990- \\
2002\end{array}$ & $\begin{array}{c}23 \text { OECD } \\
\text { members, } 5 \\
\text { Asia Countries, } \\
11 \text { Latin } \\
\text { American } \\
\text { Countries, } 16 \\
\text { Sub Saharan } \\
\text { Countries }\end{array}$ & $\begin{array}{l}\text { GDP, Incoming } \\
\text { Tourist Numbers } \\
\text { and International } \\
\text { Tourism Income }\end{array}$ & $\begin{array}{c}\text { Pedroni } \\
\text { Cointegration, Panel } \\
\text { Causality }\end{array}$ & $\begin{array}{c}\text { TUR } \rightarrow \text { Y } \\
\text { (OECD } \\
\text { Members) } \\
\text { TUR } \leftrightarrow \text { Y } \\
\text { (Non-OECD } \\
\text { Members) }\end{array}$ \\
\hline
\end{tabular}




\begin{tabular}{|c|c|c|c|c|c|}
\hline $\begin{array}{c}\text { Nowak, Sahli } \\
\text { and Cortes, } \\
2007\end{array}$ & $\begin{array}{c}1960- \\
2003\end{array}$ & Spain & $\begin{array}{l}\text { GDP and Tourism } \\
\text { Income }\end{array}$ & $\begin{array}{c}\text { Johansen } \\
\text { Cointegration and } \\
\text { Granger Causality }\end{array}$ & TUR $\leftrightarrow \mathrm{Y}$ \\
\hline Oh, 2005 & $\begin{array}{c}1975- \\
2001\end{array}$ & South Korea & $\begin{array}{c}\text { GDP and } \\
\text { International } \\
\text { Tourism Income }\end{array}$ & $\begin{array}{l}\text { Engle - Granger } \\
\text { Cointegration and } \\
\text { Granger Causality }\end{array}$ & --- \\
\hline Ohlan, 2017 & $\begin{array}{l}1960- \\
2014\end{array}$ & India & $\begin{array}{l}\text { GDP and Tourism } \\
\text { Receipts }\end{array}$ & $\begin{array}{c}\text { ARDL and Granger } \\
\text { Causality }\end{array}$ & TUR $\leftrightarrow \mathrm{Y}$ \\
\hline $\begin{array}{l}\text { Ongan and } \\
\text { Demiröz, } \\
2005\end{array}$ & $\begin{array}{c}1980- \\
2004\end{array}$ & Turkey & $\begin{array}{l}\text { GDP and Tourism } \\
\text { Income }\end{array}$ & Granger Causality & TUR $\rightarrow$ Y \\
\hline $\begin{array}{c}\text { Rodriguez, } \\
\text { Rodriguez } \\
\text { and Gallego, } \\
2015\end{array}$ & $\begin{array}{l}1980- \\
2013\end{array}$ & $\begin{array}{l}\text { UK, Spain and } \\
\text { Croatia }\end{array}$ & $\begin{array}{c}\text { GDP and Tourism } \\
\text { Receipt }\end{array}$ & GARCH Model & TUR $\leftrightarrow \mathrm{Y}$ \\
\hline $\begin{array}{c}\text { Shahzad, } \\
\text { Shahbaz, } \\
\text { Ferrer \& } \\
\text { Kumar, } 2017\end{array}$ & $\begin{array}{l}1990- \\
2015\end{array}$ & $\begin{array}{l}\text { China, France, } \\
\text { Germany, } \\
\text { Italy, Mexico, } \\
\text { Russia, Spain, } \\
\text { Turkey, UK }\end{array}$ & $\begin{array}{l}\text { GDP and Tourism } \\
\text { Expenditure }\end{array}$ & $\begin{array}{c}\text { Quantile-on-quantile } \\
\text { Approach }\end{array}$ & TUR $\leftrightarrow \mathrm{Y}$ \\
\hline $\begin{array}{c}\text { Uysal, } \\
\text { Erdoğan and } \\
\text { Mucuk, } 2004\end{array}$ & $\begin{array}{c}1992- \\
2003\end{array}$ & Turkey & $\begin{array}{l}\text { GNP and Tourism } \\
\text { Income }\end{array}$ & $\begin{array}{c}\text { Regression and } \\
\text { Granger Causality }\end{array}$ & TUR $\leftrightarrow \mathrm{Y}$ \\
\hline
\end{tabular}

Table1: Literature Review of the Studies Related to the Relationship between the Tourism Sector and Economic Growth

\begin{tabular}{|c|c|c|c|c|c|}
\hline $\begin{array}{c}\text { Vita and } \\
\text { Kyaw, 2016 }\end{array}$ & $\begin{array}{c}1995- \\
2011\end{array}$ & 129 Countries & $\begin{array}{c}\text { GDP and Tourism } \\
\text { Expenditure }\end{array}$ & $\begin{array}{c}\text { SYM - GMM } \\
\text { Estimation }\end{array}$ & --- \\
\hline Yavuz, 2006 & $1992-$ & Turkey & GDP and Tourism & Zivot Andrew & -- \\
& 2004 & & Income & $\begin{array}{c}\text { Structural Brake and } \\
\text { Todo - Yamaoato } \\
\text { Causality }\end{array}$ & \\
\hline
\end{tabular}

Y: Growth, TUR: Tourism,

$\rightarrow$ : Unilateral Relationship $\leftrightarrow$ : Bilateral Relationship, ---: No Relationship

Source: The Table is Created by the Authors.

\section{Methodology}

\section{Data Set and Model}

In this study, annual data set is used between 1977 - 2013 both for Turkey and TRNC. The period is determined by the availability of healthy data. For economic growth, GDP of both countries is used. Logarithms of all data set are taken. Logarithmic GDP of each country are indicated as LOGGDP_TR and LOGGDP_TRNC whereas logarithmic tourism revenues are indicated as LOGTOURISM_TR and LOGTOURISM_TRNC.

According to the information given above, the models that involve tourism revenues and GDP are set as below:

$$
\text { LOGGDP }_{t}=\beta_{1}+\beta_{2} \text { LOGTOURISM }_{t}+\varepsilon_{t}
$$

Where $\varepsilon_{t}$ is distributed by iid process. The graphs of the logarithmic series are indicated as below: 

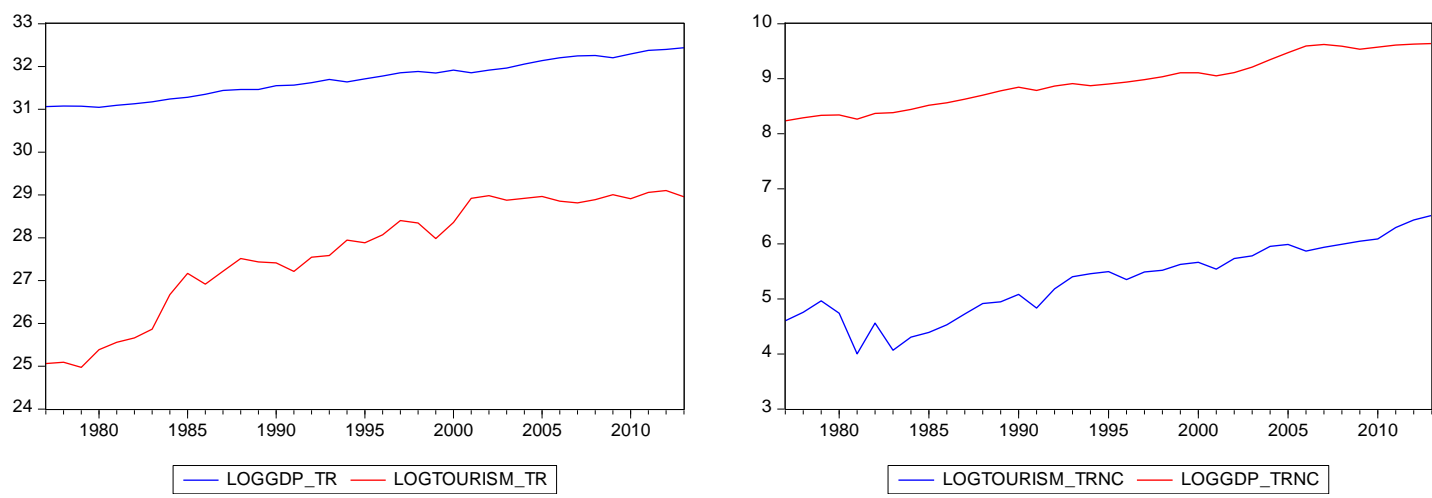

Figure 1: GDP and Tourism Revenues for Turkey and TRNC

When above figure are analyzed, it can be predicted that all the series have both intercept and trend and the potential of unit root for all the series is valid. Firstly, unit root test will be performed to understand whether the series are stationary or not.

\section{Unit Root Tests}

The most formal common tests for stationarity are unit root tests. The model of unit root stochastic process is below:

$$
Y_{t}=\rho Y_{t-1}+\mu_{t} \quad-1 \leq \rho \leq 1
$$

If $\rho=1$, there is unit root, the model is random walk without drift and it is stochastic and non-stationary process. But this process can be expanded for with drift and trend. In this situation, $Y_{t}$ is regressed over $Y_{t-1}$ value and if $\rho$ value is statistically equal to $1, Y_{t}$ is nonstationary (Bozkurt, 2007, p. 35).

If $|\rho|<1$, we can conclude that $Y_{t}$ is stationary. To determine whether approximate value of $Y_{t-1}$ is zero, a test developed by Dickey and Fuller is used (Akdi, 2003, p. 226). According to this test, null hypothesis is $\delta=0$ (or $\rho=1$, because $\delta=\rho-1$ ) and calculated $Y_{t}$ coefficient $t$ value follows $\tau$ (tau) statistics (Dickey and Fuller, 1979, p. 429).

According to Dickey - Fuller (DF) test, it is assumed that $\mu_{t}$ error term have correlation. However, there are some cases where $\mu_{t}$ is correlated. For this situation, an augmented test was developed by Dickey and Fuller (Mahadeva, 2014, p. 20). Lagged values of depended $\Delta Y_{t}$ are added to null hypothesis. Augmented Dickey-Fuller (ADF) test involves estimation of below regression:

$$
\Delta Y_{t}=\beta_{0}+\delta Y_{t-1}+\sum_{i=1}^{m} \alpha_{i} \Delta Y_{t-i}+\mu_{t}
$$

Where $\mu_{t}$ is white noise error term. The number of lagged difference terms to be added is generally calculated empirically. What should be done here is, enough terms should be added until the series have no correlation. ADF test is also based on $\alpha_{i}=0$ null hypothesis as DF test and follows the same asymptotic distribution. So, the same critical values can also be used for ADF.

Table 1 shows the results of ADF unit root tests applied to GDP and tourism revenues for Turkey. As the result of the test, tourism revenue levels is non-stationary on level, but GDP series is stationary for $10 \%$, however, when their first differences are taken, both series become stationary at $1 \%$. 
Table 2: ADF Unit Root Test Results the series on level and 1st differences

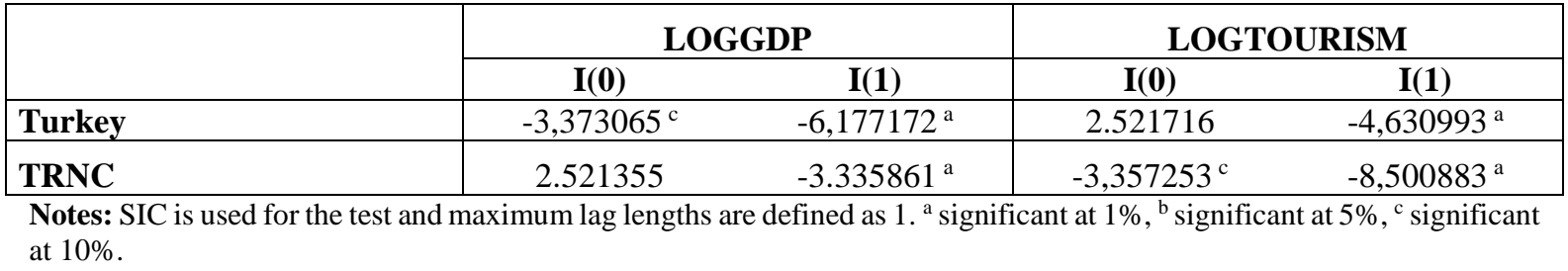

Table 1 shows the results of ADF unit root tests applied to GDP and tourism revenues for TRNC. As the result of the test, GDP levels is non-stationary on level, but tourism revenue stationary at $10 \%$, however, when their first differences are taken, both series become stationary at $1 \%$. According to ADF results Turkey and TRNC series are non-stationary on the level, however, when their first differences are taken, all the series become stationary.

Another test used for unit root is Phillips - Perron (PP). The most important assumption for DF test is error terms are independent and distributed identically. ADF test corrects serial correlation possibility of error terms by adding lagged difference terms. Phillips and Perron test uses correct serial correlation without adding lagged difference terms by using non-parametric statistical methods (Phillips and Perron, 1988, p. 345). Asymptotic distribution of PP test is the same ADF test statistics. Test results for PP test is can be seen as below:

Table 3: PP Unit Root Test Results the series on level and 1st differences

\begin{tabular}{|l|cc|cc|}
\hline \multirow{2}{*}{} & \multicolumn{2}{|c|}{ LOGGDP } & \multicolumn{2}{c|}{ LOGTOURISM } \\
\cline { 2 - 5 } & $\mathbf{I}(\mathbf{0})$ & $\mathbf{I}(\mathbf{1})$ & $\mathbf{I}(\mathbf{0})$ & $\mathbf{I}(\mathbf{1})$ \\
\hline Turkey & $-3,373065^{\mathrm{c}}$ & $-6,328935^{\mathrm{a}}$ & $-0,926720$ & $-9,876739^{\mathrm{a}}$ \\
\hline TRNC & $-2,094913$ & $-4,339717^{\mathrm{a}}$ & $-3,259560^{\mathrm{c}}$ & $-8,500883^{\mathrm{a}}$ \\
\hline
\end{tabular}

Notes: SIC is used for the test and maximum lag lengths are defined as $1 .{ }^{\mathrm{a}}$ significant at $1 \%,{ }^{\mathrm{b}}$ significant at $5 \%,{ }^{\mathrm{c}}$ significant at $10 \%$.

According to PP results Turkey and TRNC series are non-stationary on the level, however, when their first differences are taken, all the series become stationary. Like the ADF unit root test, the PP unit root test yielded similar results.

\section{ARDL Bounds Test}

The analyzing method that is used to determine long term relationship between time series is defined as cointegration analyses (Sandalcilar, 2012, p. 7). As it is indicated on previous parts, the series must be stationary to determine whether there is a relationship between the variables. However, as most of the series are not stationary in economics, it requires cointegration analyses. In real terms, even these time series are not stationary on their own, when a stationary process is created on an integrated level, long term relationship can be revealed between the variables (Bozkurt, 2007, p. 109)

Pesaran, Shin and Smith (2001) developed ARDL approach and with this method, the long term relationship between two I(1) series can be analyzed. As the lagged values of the variables are not taken into consideration, ARDL approach is used to find better results. (Sevüktekin and Çınar, 2017, p. 576).

ARDL bounds test model below:

$$
\Delta Y_{t}=a_{0}+\sum_{i=1}^{n} b_{i} \Delta Y_{t-i}+\sum_{i=1}^{n} c_{i} \Delta X_{t-i}+d_{1} Y_{t-1}+d_{2} X_{t-1}+\varepsilon_{t}
$$

In above model, $\Delta$ shows difference operator and $\varepsilon_{t}$ show independent random errors with zero mean and finite covariance matrixes. $a_{0}$ defines the fixed term while $b_{i}$ and $c_{i}$ define lag coefficient, $d_{1}$ and $d_{2}$ define cointegration coefficients. The bounds F-test is used for this 
model can be used whether there is one or more than one cointegration relationship (Jenkins ve Katırcioğlu, 2010, p. 10).

The bounds test model can be established to analyze long term relationship:

$Y_{t}=a_{0}+\sum_{i=1}^{m} a_{1 i} Y_{t-i}+\sum_{i=1}^{m} a_{2 i} X_{t-i}+\mu_{t}$

Beside the long term relationship, the short term relationship is also analyzed between the variables that have cointegration relationship. With this test, it can be resulted whether short term instabilities are corrected in long term and if they are corrected, what are the necessary duration and the amount of the correction. For this analyze, the model is established as below:

$$
\Delta Y_{t}=a_{0}+\sum_{i=1}^{m} a_{1 i} \Delta Y_{t-i}+\sum_{i=1}^{m} a_{2 i} \Delta X_{t-i}+\gamma E C T_{t-1}+\mu_{t}
$$

There are three factors which are checked while evaluating ARDL Bounds test results:

- $\quad F$-Statistic $<I(0)$ Bound $\rightarrow$ There is no cointegration relationship.

- $\quad F$-Statistic >I(1) Bound $\rightarrow$ There is cointegration relationship.

- I(O) Bound < F-Statistic < I(1) Bound $\rightarrow$ Cointegration relationship cannot be evaluated.

ARDL Bounds test results for Turkey are as below:

Table 4: ARDL Bounds Test Results for Turkey: ARDL(1,2)

\begin{tabular}{|c|c|c|}
\hline ARDL Bounds Test Statistic & Value & k \\
\hline \multicolumn{3}{|c|}{ Critical Value Bounds/Significance Level } \\
\hline & I(0) Bound & I(1) Bound \\
\hline $10 \%$ & 4,05 & 4,49 \\
\hline $5 \%$ & 4,68 & 5,15 \\
\hline $2,5 \%$ & 5,30 & 5,83 \\
\hline $1 \%$ & 6,10 & 6,73 \\
\hline
\end{tabular}

Notes: The appropriate model is Case IV (Pesaran et al., 2001: 296).

As it can be seen from the above results, F-Statistic value is above $I(1)$ bound for $5 \%$ level and above. As the result of this test, we can conclude that there is a cointegration relationship between Turkey's GDP and tourism revenues.

After the cointegration relationship between GDP and Tourism Revenues for Turkey is revealed, we can use ARDL Model for short term and long term predictions. Long term ARDL model will be as below:

LOGGDP_TR $=\alpha_{0}+\sum_{i=1}^{k} \alpha_{1 i} L O G G D P_{-} T R_{t-i}+\sum_{i=0}^{l} \alpha_{2 i}$ LOGTOURISM_TR $R_{t-i}+u_{t}$

In above model, $k$ and $l$ indicate lag lengths. Akaike Information Criteria (AIC) is used to find above lag lengths. According to AIC, Turkey's GDP will be predicted with 1 length while Turkey's tourism revenues will be predicted with 2 lengths. According to this, the model will be $\operatorname{ARDL}(1,2)$. below:

The long term coefficients gathered by using ARDL $(1,2)$ model are going to be as

Table 5: Long Term Coefficients predicted with ARDL $(1,2)$ model

\begin{tabular}{|l|cccc|}
\hline \multicolumn{5}{|c|}{ Long Term Coefficients } \\
\hline Variable & Coefficient & Std. error & t-stat. & Prob. \\
\hline LOGTOURISM_TR & 0,052555 & 0,030508 & 1,722647 & 0,0956 \\
@TREND & 0,034292 & 0,003712 & 9,238446 & 0,0000 \\
\hline
\end{tabular}


As it can be seen in Table 4, t-statistic value of Turkey's tourism revenues is significant within $10 \%$ significance level whereas the t-statistic value of trend parameter is significant within $1 \%$ significance value. As GDP is dependent variable and tourism revenues are independent variable, the linear function can be written as below:

As it is indicated in above equation, the coefficient of Turkey's tourism revenues is 0,052555 . According to this coefficient, when Turkey's tourism revenues increase one $1 \%$ in long term, Turkey's GDP increases by $0,05 \%$ and we can conclude that there is long term positive cointegration relationship between these series.

Error correction model should be analyzed to figure out whether there is short term relationship between Turkey's GDP and tourism revenues. The error correction model is found as below:

Table 6: ARDL Error Correction Model for Turkey

\begin{tabular}{|c|c|c|c|c|}
\hline $\begin{array}{l}\text { Dependent Variable: D(LOC } \\
\text { Sample: } 19772013\end{array}$ & & & & \\
\hline Variable & Coefficients & Std. Err. & t-stat. & Prob. \\
\hline Constant & $17,076285^{\mathrm{a}}$ & 4,031990 & 4,235200 & 0,0002 \\
\hline D(LOGTOURISM_TR) & $-0,009138$ & 0,248812 & 0,36827 & 0,7153 \\
\hline D(LOGTOURISM_TR(-1)) & $-0,047157^{c}$ & 0,026636 & $-1,77043$ & 0,0872 \\
\hline ECT(-1) & $-0,574672^{a}$ & 0,136019 & $-4,22495$ & 0,0002 \\
\hline R_sqr & 0.37 & & DURBIN-WATSON & 1.8871 \\
\hline Adj. R_sqr & 0.31 & & ARCH (1) & 0.0705 \\
\hline Sum Sqr. Resid & 0.0404 & & ARCH (2) & 2.0167 \\
\hline F-statistics (Prob.) & $6.0790^{\mathrm{a}}(0.0022)$ & & ARCH (3) & 1.2287 \\
\hline Breusch-Pagan-Godfrey & 0.6270 & & & \\
\hline White & 1.1481 & & & \\
\hline Breusch-Godfrey_LM(2) & 0.2272 & & & \\
\hline Breusch-Godfrey_LM(3) & 0.1810 & & & \\
\hline
\end{tabular}

Notes: ${ }^{\mathrm{a}}$ significant at $1 \%,{ }^{\mathrm{b}}$ significant at $5 \%,{ }^{\mathrm{c}}$ significant at $10 \%$.

Above results indicate both short term and error correction test results for ARDL $(1,2)$ model. Firstly, all above series are cleared from diagonistik tests. According to above data, GDP values of the current term is affected from the GDP values of the one previous term. The value is significant as it can be indicated from the $t$-stats.

The coefficient should be negative and significant for the error correction model. As it can be seen from Table 7, the coefficient in the model is $-0,5746$ and it shows that the error correction model works. Also, the value of t-statistic is $-4,224952$ and it significant within $1 \%$ level.

According to the error correction model, 5,7\% of the short term deviations can be corrected for the next term as in the long term balance. All the deviations goes back to the long term balance in 17,54 terms, which means almost 1,5 years.

The coefficient of short term effect of tourism revenues on GDP is significant for the one previous term. According to this coefficient, the $1 \%$ change of tourism revenues in one previous term affects the current GDP for $0,0047 \%$. According to this coefficient, the effect of tourism revenues is pretty weak for the short term. below:

ARDL Bounds test results for LOGGDP_TRNC and LOGTOURISM_TRNC are as 
Table 7: ARDL Bounds Test Results for TRNC: ARDL(3,2)

\begin{tabular}{|l|cc|}
\hline $\begin{array}{l}\text { ARDL Bounds Test Statistic } \\
\text { F-Statistic }\end{array}$ & $\begin{array}{c}\text { Value } \\
2,404706\end{array}$ & $\mathbf{k}$ \\
\hline Critical Value Bounds/Significance Level & & \\
\hline & I(0) Bound & I(1) Bound \\
\hline $\mathbf{1 0 \%}$ & 2.44 & 4.28 \\
$\mathbf{5 \%}$ & 3.15 & 4.92 \\
$\mathbf{2 , 5 \%}$ & 3.88 & 6.02 \\
\hline $\mathbf{1 \%}$ & 4.81 & \\
\hline
\end{tabular}

Notes: The appropriate model is Case I (Pesaran et al., 2001: 295).

As it can be seen from the above results, F-Statistic value is below $I(0)$ bound for $5 \%$ level and below. As the result of this test, we can conclude that there is no cointegration relationship between TRNC's GDP and tourism revenues. As we cannot find any cointegration relationship for TRNC, there is no need for further analyses.

\section{Conclusion}

In this study, the long-run relationship between economic development and tourism revenues is studied both for Turkey and Turkish Republic of Northern Cyprus. The series between 1977 and 2013 are used to research the relationship. Tourism led growth hypothesis (TLGH) is totally valid for Turkey according to the results and it means that the economic activities that supports the development of tourism sector should be supported. As ARDL test results reveals, tourism policies are both efficient in short term and long term. However, as long term coefficient is higher that short term coefficient, it proves that long term tourism policies are more beneficial than short term policies. It is important to focus on long term policies to achieve higher returns on economic development.

The test results show that TLGH is not valid for TRNC, which means that the increase in tourism revenues does not affect the economic growth. However, we cannot conclude that tourism sector should be ignored in TRNC. TRNC is an island country and receives many tourists every year and it is very obvious that tourism revenues has a share in GDP and creates employment. The geographical advantage of TRNC should be used much efficiently to make the sector create more impact on economic development.

\section{References}

Akdi, Y. (2003) Zaman serileri analizi: birim kökler ve kointegrasyon (1.Baskı) Bıçakçılar Kitapevi.

Aslan, A. (2008). Türkiye'de ekonomik büyüme ve turizm ilişkisi üzerine ekonometrik analiz. Munich Personel RePEc Archieve, Paper No: 10611.

Bozkurt, H. (2007) Zaman serileri analizi (1. Bask1) Ekin Kitapevi.

Brau R. \& Lanza, A. \& Pigliaru, F. (2007). How Fast Are Small Tourism Countries Growing? Evidence From The Data For 1980-2003. Tourism Economics, 13, 603-613

Brida, J. G. \& Pulina, M. (2010). A Literature Review on the Tourism-Led-Growth Hypothesis. Center for North South Economic Research Working Paper, No. 2010-17.

Chang, C. L., Khamkaew, T., \& McAleer, M. (2010). IV estimation of a panel threshold model of tourism specialization and economic development. CIRJE F-Series, CIRJE-F-732, CIRJE, Faculty of Economics, University of Tokyo

Chou, M. C., (2013). Does Tourism Development Promote Economic Growth in Transition Countries? A Panel Data Analyses. Economic Modelling, 33, 226-232.

Dritsakis, N. (2004). Tourism as a Long-Run Economic Growth Factor: An Emprical Investigation for Greece Using Causality Analyses. Tourism Economics, 10(3), 305316. 
Gujarati, D. N. (2004) Basic econometrics (Fourth Ed.) The McGraw Hill Companies.

Jenkins, H. P. \& Katıcıoğlu, S. (2010). The Bounds Test Approach for Cointegration and Causality between Financial Development, International Trade and Economic Growth: The Case of Cyprus. Applied Economics, 42(13), 1699-1707.

Kaplan, M. \& Çelik, T. (2008). The Impact of Tourism on Economic Performance: The Case of Turkey. The International Journal of Applied Economics and Finance, 2(1), 13-18.

Khalil, S., Kakar, M. K. \& Waliullah, A. M. (2007). Role of Tourism and Economic Growth: Empirical Evidence from Pakistan Economy. The Pakistan Development Review, 46(4), 985-995.

Kızılgöl Ö. \& Erbaykal, E. (2008). Türkiye'de turizm gelirleri ile ekonomik büyüme ilişkisi: Bir Nedensellik Analizi. Süleyman Demirel Üniversitesi İktisadi ve İdari Bilimler Fakültesi Dergisi, 13(2), 351-360.

Kruger, A. O. (1980). Trade Policy as an Input to Development. American Economic Review, 70, 188-292.

Kumar, R.R. \& Stauvermann, P.P. (2016). The linear and non-linear relationship between of tourism demand and output per worker: A study of Sri Lanka, Tourism Management Perspectives, 19, $109-120$.

Lee, C. C. \& Chang, C. P. (2008). Tourism Development and Economic Growth: A Closer Look at Panels. Tourism Management, 29, 180-192.

Lejarraga, I. \& Walkenhorst, P. (2013). Economic Policy, Tourism Trade and Productive Diversification. CEPII, WP, No: 2013-07.

Mahadeva, L. \& Robinson, P. (2004). Unit Root Testing to Help Model Building. Center for Central Banking Studies. Bank of England, London.

McKinnon, D.R.I. (1964). Foreign Exchange Constraint in Economic Development and Efficient Aid Allocation. Economic Journal, 74, 388-409.

Narayan, P. K. (2007). Testing Convergence of Fiji's Tourism Markets. Pacific Economic Reviews, 12(5), 651-663.

Nowak, J. J. \& Sahli, M. \& Sgro, P. M. (2003). Tourism, Trade and Domestic Welfare. Pacific Economic Review, 8(3), 245-258.

Oh, C. O. (2005). The Contribution of Tourism Development to Economic Growth in the Korean Economy. Tourism Management, 26, 39-44.

Ohlan, R. (2017). The relationship between tourism, financial development and economic growth in India, Futures Business Journal, 3(1), 9 - 22.

Ongan, S. \& Demiröz, D. M. (2005). The Contribution of Tourism to the Long-Run Turkish Economic Growth. Journal of Economics, 53(9), 880-894.

Paci, R. \& Marrocu, E. (2013). Tourism and Regional Growth in Europe. Papers in Regional Sciences, 93, 25-50.

Pesaran, H. \& Shin, Y. \& Smith, R. J. (2001). Bound Testing Approaches to the Analysis of Long Run Relationships. Journal of Applied Econometrics, 16(3), 289-326.

Phillips, P. C. B. \& Perron, P. (1988). Testing for a Unit Root in Time Series Regression. Biometrika, 75, 335-346.

Rodriguez, J. V. P., Rodriguez, F. L., \& Gallego, M. S. (2015). Testing dependence between GDP and tourism's growth rates, Tourism Management, 48, 268 - 282

Sandalcılar, A. R. (2012). Türkiye'de kağıt tüketimi ile ekonomik büyüme arasındaki ilişki: Eşbütünleşme ve nedensellik analizi. C. Ü. İktisadi ve İdari Bilimler Dergisi, 13(2), 2 15.

Sevüktekin, M. \& Çınar M. (2017) Ekonometrik zaman serileri analizi: Eviews uygulamalı (5. Baskı) Dora Basım Yayım. 
Shahzad, S. J. H., Shahbaz, M., Ferrer \& Kumar, R.R. (2017) Tourism-led growth hypothesis in the top ten tourist destinations: New evidence using the quantile-on-quantile approach, Tourism Management, 60, 223-232

Smith, E. J. M. (2001). Is the Export - Led Growth Hypothesis Valid for Developing Countries? A Case Study of Costa Rica. United Nations Policy Issues in International Trade and Commodities: Study Series No. 7.

Uysal, D., Erdoğan, S. \& Mucuk, M. (2004). Türkiye'de Turizm Gelirleri ve Ekonomik Büyüme Arasındaki İlişki (1992 - 2003). SÜ İ̈BF Sosyal ve Ekonomik Araştırmalar, Dergisi, 4(8), 163-170.

World Travel and Tourism Council (2006). Country Report: Fiji. World Travel and Tourism Council.

Vita, G. D., Kyaw, K. S. (2016), Tourism Development and Grpwth, Annals of Tourism Research, 60, 23 - 26.

Yavuz, N. Ç. (2006). Türkiye'de turizm gelirlerinin ekonomik büyümeye etkisinin testi: Yapısal kırılma ve nedensellik analizi. Doğuş Üniversitesi Dergisi, 7(2), 162 - 171. 